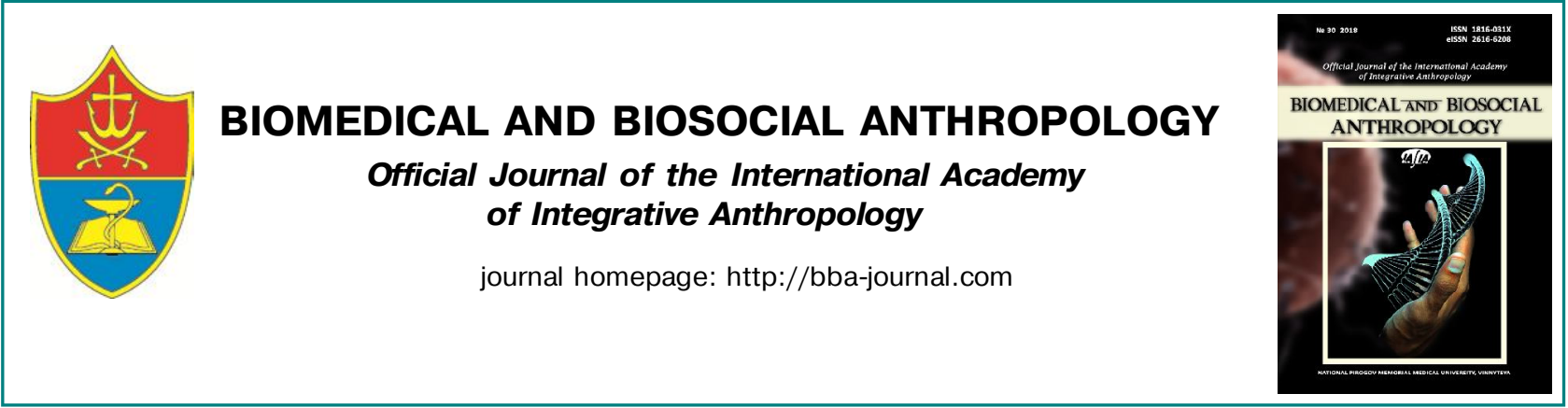

\title{
Modeling using regression analysis of linear sizes of molars depending on the cephalometric indices of practically healthy men of the Northern and Southern regions of Ukraine
}

\section{Kotsyura 0.0 .}

National Pirogov Memorial Medical University, Vinnytsya, Ukraine

\section{ARTICLE INFO}

Received: 1 December, 2017

Accepted: 22 January, 2018

UDC: $611.314: 616.714 .1-071.3: 79-$ 055.1(477)

\section{CORRESPONDING AUTOR}

e-mail: olyatkokotsyura@gmail.com Kotsyura O. O.
For more precise odontometry, taking into account the individual craniotypological features of the patient, mathematical modeling should be used, which will significantly improve the quality of the medical diagnostic and treatment process in orthodontics. The purpose of the study is to construct and analyze a regression model of computer tomographic size of molars, depending on the features of cephalometric indices of practically healthy men of the Northern and Southern regions of Ukraine. Computertomographic study of molars with the following odontometry and cephalometry of 32 practically healthy men of the Northern region of Ukraine - residents from Zhytomyr, Kyiv, Chernihiv and Sumy regions and 33 men of the Southern region of Ukraine - residents from Odessa, Nikolaev, Kherson, Zaporizhzhya regions and Crimea. The construction of regression models of individual linear sizes of molars, depending on the cephalometric indices, was performed using the statistical software package "Statistica 6. 1". As a result of our research, we have constructed reliable models of linear computational-tomographic sizes of molars of the upper and lower jaws in practically healthy men of the North [3 models of mesio-distal dimensions $\left(R^{2}=0.576-0.685\right)$, to which most often include the length of the body of the mandible on the right(16.7\%), the smallest width of the head, the depth of the nose and the craniotype (by 11.1\%); 2 models of vestibular-tongue dimensions $\left(R^{2}=0.657\right.$ and 0.767$)$, which most often include the transverse arc and the smallest width of the head (15.4\%); 2 models of crown height $\left(R^{2}=0.519\right.$ and $0.557)$ ] and Southern [4 models of mesio-distal dimensions $\left(R^{2}=0.508-0.798\right)$, which most often include the largest head length, average facial width, height of the upper face, physiological face length, width of the lower jaw, nose depth and external eye width (8.3\%); 6 models of vestibular-tongue dimensions $\left(R^{2}=0.504-0.756\right)$, which most often include external eye width (13.2\%), physiological facial length, intercostal width and mouth width (10.5\%), maximum head width, length and height of the nose (by $7.9 \%)$, transverse arc, height of the upper face and distance between the nasion and inter-incisive point (by 5.3\%); 2 models of crown height $\left(R^{2}=0.527\right.$ and 0.748 ), which most often include inter-orbital width and mouth width (14.3\%)] regions of Ukraine. Thus, in practically healthy men from the Northern and Southern administrative-territorial regions of Ukraine, based on the characteristics of cephalometric indicators, craniotype and face type, reliable regression models (with determination coefficient $R^{2}$ greater than 0.5) of individual linear computer tomography sizes of molars of the upper and lower jaws (out of 40 possible 7 for Northern and 12 for Southern regions of Ukraine).

Keywords: regression models, molars, linear dimensions, computer tomography, cephalometry, practically healthy men, Northern and Southern regions of Ukraine.

\section{Introduction}

One of the most common methods for statistical processing of databases is regression analysis. It is the main component of the teaching of mathematical models in biology and medicine, and without using this method it is impossible to get a complete picture of the true nature of the multiple relationships between the studied parameters of living systems [4]. 
With the help of regression equations, knowing the magnitude of one of the studied characters, it is possible to determine with sufficient degree of accuracy the value of another, paired with it. On the basis of regression analysis it is possible to construct an entire system of forecasts, and to use the obtained equations in the determination of parameters, the direct measurement of which under normal circumstances is difficult or impossible [11].

There is enormous experience in using different types of regression analysis in the field of biomedical anthropology. Such studies are always populational-specific, since one or another anthropological signs of man vary depending on ethnicity, climatic and geographical conditions of residence $[15,16]$.

Restoration of the teeth tissues should be carried out, as close as possible to the natural anatomical features of the maxillofacial area of the individual. Lack of knowledge about the dimensional characteristics of teeth and accurate calculations of their morphometric indices leads to medical errors $[12,14,18]$. A comprehensive approach is needed to achieve sustainable and guaranteed clinical success. Dentistry doctors need objective information not only about the size of the teeth, but also about their interactions with the parameters of the skull $[2,3,6,5]$.

For more precise odontometry, taking into account the individual craniotypological features of the patient, mathematical modeling should be used, which will significantly improve the quality of the medical diagnostic process in orthodontics, providing an opportunity for a more profound analysis of clinical information.

The purpose of the study is to construct and analyze a regression model of computer tomographic size of molars, depending on the features of cephalometric indices of practically healthy men of the Northern and Southern regions of Ukraine.

\section{Materials and methods}

As a result of a previous survey conducted by a team of researchers, from more than 3500 men aged from 19 to 35 from different regions of Ukraine were selected 200 healthy people, inhabitants of different administrativeterritorial regions in the third generation with susceptible, moderately susceptible and satisfactory ecological living conditions, according to researches of the National Ecological Center of Ukraine. Among them: Northern region - 32 inhabitants from Zhytomyr, Kiev, Chernihiv and Sumy regions; Southern region - 33 inhabitants from Odessa, Nikolaev, Kherson, Zaporizhzhya regions and Crimea. All of them had a cephalometric research (based on the Department of Pediatric Dentistry and Research Center of National Pirogov Memorial Medical University, Vinnytsya) and computer-tomographic (based on the private dental clinic "Vinintermed LTD").

Bioethics Committee of National Pirogov Memorial Medical University, Vinnytsya found that the studies fully met ethical and moral-legal requirements in accordance with the order of the Ministry of Health of Ukraine No. 281 of November 1, 2000 and do not contradict the basic bioethical norms of the Helsinki Declaration, the Council of Europe Convention Human Rights and Biomedicine (1977).

Cone-ray computed tomography was performed using the Veraviewepocs-3D dental cone-ray tomograph (Morita, Japan). The volume of a three-dimensional image is a cylinder of $8 \times 8 \mathrm{~cm}$, a layer thickness of $0.2 / 0.125 \mathrm{~mm}$, an irradiation dose of 0.011-0.048 mSv, a voltage and a current of $60-90 \mathrm{kV} / 2-10 \mathrm{~mA}$. The study of a three-dimensional model of bone structures of the tooth-jaw complex was carried out in the i-Dixel One Volume Viewer (Ver.1.5.0, J Morita Mfg. Cor.) program envelope. On tomograms of molars of the upper and lower jaws measurements were made: height of the crown of the corresponding tooth; vestibular-tongue dimensions of the crown and neck of the tooth; mesio-distal dimensions of the crown and neck of the corresponding tooth [22].

The cephalometric study was conducted taking into account the generally accepted recommendations and anatomical points [1], and included the determination of parameters of the cerebral [the largest head circumference through hypertension (glabella) and inion (DUG_GOP); the transverse arc measured by the ribbon from the right goose point to the left (DUG_AUAU); sagittal arc, measured by the tape from the glabella to the occipital point (DUGS_GOP); the largest length of the head is the distance from the glabella to the opisthokranion (G_OP); maximum head width (occipital diameter, EU_EU); the smallest head width (frontal diameter, FMT_FMT)] and facial [face width, is the distance between zygomatic points ( $Z Y$ ZZY); average width of the face, is the distance between the zygomatic maxillary points (ZM_ZM); the width of the mandible, or the width between the angles of the mandible (GO_GO); the height of the forehead is the straight distance between the points of the trichion and nasion (TR_N); physiological length of the face, is the distance from the trichion (hair growth line) to gnation (TR_GN); nose length, is the distance between the nasion and pronasion (N_PRN); nose height, is the distance between the upper nose and the lower nose points (N_SN); the depth of the nose, is the distance between the lower nose point and pronasion (SN_PRN); height of the upper face, is the distance from the nasal to the mouth point (N_STO); the distance between the nasion and the interincisive point (N_I); morphological length of the face, is the direct distance from the nasion to the gnation (N_GN); interorbital width (front inter-orbital width), is the straight line distance between the inner corners of the eye pits (MF_MF); foreign eye width (bi-orbital width), this is the direct size between the outer angles of the eye gaps (EK_EK); the width of the base of the nose (the distance between the dots points, $\left.A L \_A L\right)$; mouth width $\left(\mathrm{CHI}_{-} \mathrm{CHI}\right)$; the length of the body of the mandible on the right (RGO_GN); the length of the body of the lower jaw on the left (LGO_GN)] department of the head with the help of a large sliding compass with a scale in the real size of the Martin system 
and a soft centimeter ribbon. The shape of the head was determined according to the following formula [25]: EU_EU / G_OP $\times 100$. Up to 75.9 men belonged to dolichocephalic; 76.0-80.9 - to mesocephalic; 81.0-85.4 - for brachycephalic; 85.5 and more - to hyperbrachycephalic. The value of the face index (Garson morphological index) was obtained according to the corresponding formula [17]: N_GN / ZY_ZY $x 100$. Up to a value of 78.9 , the men belonged to the group with a very wide face; 79.0-83.9 - with a wide face; 84.0-87.9 - with middle face; 88.0-92.9 - with a narrow face; 93.0 and more - with a very narrow face.

The construction of regression models of individual linear sizes of molar, depending on the cephalometric indices, was conducted using the statistical software package "Statistica 6.1". In the direct stepwise regression analysis, the following conditions are defined: the final version of the model must have a determination coefficient $\left(R^{2}\right)$ at least 0.50 , the value of the F-criterion is not less than 2.5 , and the number of free members included in the model must be minimal.

\section{Results}

Reliable regression models of computer-tomographic linear sizes of large angular teeth have been constructed depending on the features of cephalometric indices, craniotype and the face of practically healthy men from the Northern and Southern regions of Ukraine, have following linear equations:

vestibular-tongue size of the cervix of the upper right first molar (northern region $)=11.73+0.373 \times$ DUG AUAU -1.029 $\times$ CHI_CHI $+0.228 \times$ FMT_FMT $-0.680 \times$ RGO_GN +0.819 $\times$ N_I - $0.764 \times$ N_GN $\left(R^{2}=0.767 ; F_{(6.25)}=13.70 ; p<0.001\right.$; Error of estimate $=0.412$ );

vestibular-tongue size of the crown of the upper right first molar (northern region) $=-1.055+0.731 \times$ FMT_FMT +0.298 $x$ DUG AUAU - $0.688 \times$ MF MF - $0.568 \times$ ZY ZY + $0.337 x$ EK_EK - $0.209 \times$ TIP_LICA $+0.477 \times$ N_STO $\left(R^{2}=0.657\right.$ $F_{(6.56)}=7.24 ; p<0.001$; Error of estimate $\left.=0.399\right)$;

mesio-distal size of the neck of the lower left second molar (northern region) $=5.319-0.819 \times$ SN PRN $-0.599 \times$ RGO_GN + $0.262 \times$ DUG_GOP $-0.179 \times$ G_OP $+0.061 \times$ N_SN + $0.084 \times$ TIP_LICA $\left(R^{2}=0.576 ; F_{(5.66)}=6.25 ; p<0.001\right.$; Error of estimate $=0.394)$;

height of the crown of the lower left of the first molar (northern region) $=0.770+0.649 \times \mathrm{N} \_$STO $-0.559 \times \mathrm{CHI} C \mathrm{CHI}$ $+0.149 \times$ DUG GOP $+0.928 \times$ SN PRN $-0.389 \times \mathrm{N}$ I $\left(R^{2}=0.519 ; F_{(5.26)}=5.61 ; p<0.01\right.$; Error of estimate $\left.=0.521\right)$;

mesio-distal size of the neck of the lower left first molar (northern region) $=14.72-0.554 \times$ TIP GOL $+0.260 \times$ FMT_FMT - $1.013 \times$ RGO_GN + $0.306 \times \overline{E U}$ EU $-0.640 x$ SN_PRN $\left(R^{2}=0.622 ; F_{(5.26)}=8.55 ; p<0.001\right.$; Error of estimate $=0.454$ );

height of the crown of the lower right first molar (northern region) $=-0.529+0.658 \times$ LGO_GN $-1.595 \times \mathrm{AL} A \mathrm{AL}+$ $0.273 \times$ EK_EK $+0.160 \times$ TIP_LICA $+0.279 \times$ GO_GO $\left(R^{2}=0.557 ; F_{(5.26)}=6.54 ; p<0.001 ;\right.$ Error of estimate $\left.=0.492\right)$;

mesio-distal size of the neck of the lower right first molar $($ northern region $)=18.85+0.148 \times$ FMT_FMT $-0.556 \times$ N_GN $-0.402 \times$ TIP_GOL $-1.247 \times$ RGO_GN + 0.407 $x$ EK_EK $+0.136 \times$ DUGS_GOP $-0.093 \times \mathrm{ZM} Z \mathrm{ZM}\left(\mathrm{R}^{2}=0.685 ; \mathrm{F}_{(7.24)}=7.44\right.$; $\mathrm{p}<0.001$; Error of estimate $=0.384)$;

mesio-distal crown size of the upper right first molar (southern region) $=4.191-0.901 \times$ GO GO - 2.024 x SN PRN $+0.660 \times$ G_OP $+1.083 \times$ ZY_ZY $-2.826 \times$ EK_EK + 1.050 $x$ ZM_ZM + $0.324 \times$ DUGS_GOP $-0.482 \times$ TIP_LICA $\left(R^{2}=0.798\right.$; $F_{(8.24)}=11.84 ; p<0.001$; Error of estimate $\left.=0.756\right)$;

mesio-distal crown size of the upper left second molar (southern region) $=10.74-0.531 \times$ GO_GO $-1.886 \times$ EK_EK $+1.280 \times A L A L+0.568 \times Z Y Z Y+0.361 \times Z M Z M+0.373$ $x$ G_OP $\left(R^{2}=0.622 ; F_{(6.26)}=7.12 ; p<0.001\right.$; Error of estimate $=0.701)$;

vestibular-tongue size of the neck of the lower left second molar (southern region) $=2.138+0.315 \times \mathrm{N}$ PRN +2.280 $x$ MF_MF -0.924 x N_STO $-0.456 x$ TR_GN + 1.109vCHI_CHI - $0.970 \times$ EK_EK + $1.146 \times$ EU_EU - $0.179 \times$ DUGS_GOP $\left(R^{2}=0.756 ; F_{(8.24)}=9.31 ; p<0.001 ;\right.$ Error of estimate $\left.=0.652\right)$;

vestibular-tongue size of the crown of the lower left of the second molar (southern region) $=5.946+0.223 \times$ N_PRN $-1.065 \times$ AL_AL $-1.794 \times$ EK_EK + $0.967 \times$ CHI CHI + 1.340 $\times$ MF_MF + $0.978 \times$ EU_EU + 0.425vFMT_FMT - $0.293 \times$ TR_GN $\left(R^{2}=0.706 ; F_{(7.22)}=8.24 ; p<0.001\right.$; Error of estimate $=0.663)$;

vestibular-tongue size of the neck of the lower left first molar (southern region) $=7.870+0.177 \times \mathrm{N} \_S N+1.130 \times$ MF_MF - $0.690 \times$ N_STO $-0.336 \times$ TR_GN $+0.569 \times$ EU_EU - $0.635 \times$ EK_EK + $0.129 \times$ ZY_ZY $\left(R^{2}=0.633 ; F_{(6.16)}=7.25\right.$; $\mathrm{p}<0.001$; Error of estimate $=0.458$ );

vestibular-tongue size of the crown of the lower left first molar (southern region) $=17.23+0.129 \times \mathrm{N}$ SN $-0.522 \times$ $\mathrm{N} \_\mathrm{I}-0.175 \times$ G_OP $\left(\mathrm{R}^{2}=0.504 ; \mathrm{F}_{(3.29)}=9.81 ; \mathrm{p}<0.001\right.$; Error of estimate $=0.480$ );

height of the crown of the lower right first molar (southern region) $=18.12-1.145 \times$ SN_PRN $-0.620 \times$ EU_EU -0.558 $x$ MF_MF $-0.113 \times$ N_PRN $-0.218 \times$ TIP_LICA $+0.590 \times$ LGO_GN - $0.636 \times$ CHI_CHI $+0.424 \times$ N_STO $\left(R^{2}=0.748\right.$; $F_{(8.24)}=8.89 ; p<0.001 ;$ Error of estimate $\left.=0.357\right)$;

mesio-distal crown size of the lower right first molar (southern region) $=24.38+0.155 \times$ N_PRN $-0.959 \times$ RGO_GN + 
$1.000 \times$ CHI_CHI $-0.979 \times$ N_STO $-0.185 \times$ TR_GN -0.154 $x$ DUG_AUAU $\left(R^{2}=0.560 ; F_{(6.26)}=5.51 ; p<0.001\right.$; Error of estimate $=0.674)$;

vestibular-tongue size of the neck of the lower right second molar (southern region) $=6.611+0.204 \times$ N_PRN $+1.360 x$ MF_MF $-0.712 \times$ EK_EK $+0.617 \times$ CHI_CHI $-0.262 \times$ TR_GN $+0.186 \times$ DUG_AUAU $\left(R^{2}=0.549 ; F_{(5.27)}=6.26 ; p<0.01\right.$; Error of estimate $=0.781$ );

vestibular-tongue size of the crown of the lower right second molar (southern region) $=14.27+0.217 \times \mathrm{N} \_\mathrm{SN}$ $0.583 \times \mathrm{N} \_-0.771 \times$ EK_EK $+0.951 \times \mathrm{CHI} C \mathrm{CHI}+0.182 \times$ DUG_AUAU - 0.341 xGO_GO $\left(R^{2}=0.619 ; F_{(6.26)}=7.04 ; p<0.001\right.$; Error of estimate $=0.704)$;

height of the crown of the lower right second molar (southern region) $=15.35-0.718 \times$ TR_GN $-1.328 \times$ MF_MF $+0.169 \times$ DUGS_GOP $+0.649 \times$ TR_N $+1.172 \times$ AL_AL $0.965 \times$ CHI_CHI $\left(R^{2}=0.527 ; F_{(6.26)}=4.83 ; p<0.01\right.$; Error of estimate $=0.705)$;

mesio-distal crown size of the lower right second molar ( southern region) $=17.06+0.178 \times \mathrm{N} \_S N-0.987 \times$ SN_PRN - $0.244 \times$ TR_GN - $0.504 \times$ N_STO $\left(R^{2}=0.508 ; F_{(4.28)}=7.22\right.$; $\mathrm{p}<0.001$; Error of estimate $=0.521$ );

where $\mathrm{R}^{2}$ - coefficient of determination; $\mathrm{F}_{(\text {!!!! })}=$ !!.!! - critical (!!!!) and got (!!.!!) value of Fisher's criterion; St. Error of estimate - standard error of the standardized regression coefficient; sizes of head and face - in sm; TIP_LICA - type of face ( 1 wide. 2 medium. 3 narrow. 4 very narrow); TIP_GOL - craniotype (1 - dolichocephalic. 2 mesocephalic. 3 - brachycephalic. 4 -hyperbrachycephalic).

Regression models of all other linear sizes of molars in practically healthy men of the Northern and Southern regions of Ukraine have a determination coefficient less than 0.5 and therefore have no significance for practical dentistry.

\section{Discussion}

A number of studies have established the relationship between the size of teeth and cephalometric indices [7. 8. 9]. When making a decision on surgical manipulation. the doctor is guided by a large number of individual factors inherent in the patient. It is determined that the ratio of such two components as the tooth-jaw system and the craniofacial complex are critical in providing the function of chewing and articulation movements. the protection of the temporomandibular joints. the change in the shape and location of the occlusion plane. the determination of the processes of reduction and age-related changes [19].

Distributed algorithms for restoration of normal occlusion are based on the integration of data on the parameters of the teeth and skull of a particular patient. focusing on their morphofunctional unity [21. 24]. This approach is individualized. in the world literature it is called "personified" and is substantially distributed among doctors of the last 57 years [20. 21. 23. 24]. Simulation of the size of the teeth by the cranial parameters is increasingly interested in dental doctors and orthodontists. Available information programs represent a practical interest in the development of aesthetic dentistry [10].

As a result of our research. by means of regression analysis. reliable models (with determination coefficient $R^{2}$ greater than 0.5 ) of linear computer-tomographic sizes of molars of the upper and lower jaws were constructed based on the features of cephalometric indices. craniotype and face type in practically healthy men of the North ( 3 models of mesio-distal dimensions of the cervix of the mandible. $\mathrm{R}^{2}=0.576-0.685 ; 2$ models of vestibular-tongue teeth size of the upper jaw. $R^{2}=0.657$ and $0.767 ; 2$ models of the height of crowns of the lower teeth of lower jaw. $\mathrm{R}^{2}=$ 0.519 and 0.557 ) and Southern (4 models of mesio-distal sizes of the crown of the upper and lower jaw teeth. $\mathrm{R}^{2}=$ 0.508-0.798; 6 models of vestibular-tongue dimensions of the crown and neck of the mandible. $R^{2}=0.504-0.756 ; 2$ models of the height of crowns of the mandible. $\mathrm{R} 2=0.527$ and 0.748 ) of the regions of Ukraine.

Constructed models of individual computer-tomographic linear sizes of molars of the upper and lower jaws with a determination coefficient of more than 0.5 most often include:

in men of the Northern region of Ukraine. features of the facial part head are $61.0 \%$ (the length of the body of the mandible on the right is $9.8 \%$. the outer eye width and depth of the nose is $7.3 \%$. the height of the upper face part. the distance between the nasion and the inter-incisive point. the morphological length of the face and the width of the mouth gap - by $4.9 \%$ ). the parameters of the cerebral part of $26.8 \%$ (the smallest width of the head $-9.8 \%$. the largest head circumference of head and transverse arc by $4.9 \%$ ). face type $7.3 \%$ and craniotype $4.9 \%$; individually to models of mesio-distal sizes - the length of the body of the mandible to the right (16.7\%). the smallest head width. the depth of the nose and the craniotype (by $11.1 \%$ ); to models of vestibular-tongue dimensions - the transverse arc and the smallest width of the head (by 15.4\%);

among men of the Southern region of Ukraine - the parameters of the facial head of the head $75.8 \%$ (physiological length of the face. the width of the mouth and the outer-eye width $-10.6 \%$. inter-orbital width $-9.1 \%$. length of the nose $-7.6 \%$. height of the upper facial features and nose height $-6.1 \%$; facial width. nasal base width. nose depth and width of the mandible $-4.5 \%$ ). brain part of head parameters $21.2 \%$ (maximum head width $-6.1 \%$ . transverse arc. sagittal arc and maximum head length by $4.5 \%$ ) and face type $3.0 \%$; individually to models of mesio-distal dimensions - the largest length of the head. average facial width. height of the upper face. physiological face length. width of the mandible. nasal depth and outereye width $(8.3 \%)$; to models of vestibular-tongue dimensions - external-eye width (13.2\%). physiological face 
length. inter-orbital width and mouth width (by $10.5 \%$ ). maximum head width. length and height of the nose (7.9\%). transverse arc. height of the upper part of the face and distance between the nasion and the inter-incisive point (by $5.3 \%$ ); to models of crown height - inter-orbital width and mouth width (by $14.3 \%$ ).

Comparing the results we obtained with the results of modeling the linear dimensions of premolars [13] it should be noted: in men of the Northern region of Ukraine. 6 models of mesio-distal dimensions $\left(R^{2}=0.562-0.715\right)$ were constructed. which most often include the transverse arc and the width of the mouth $(10.5 \%)$ and the width of the base of the nose. the width of the lower jaw and the length of the body of the mandible on the left (by $7.9 \%$ ); 4 models of vestibular-tongue dimensions $\left(R^{2}=0.525-0.822\right)$. which most often include the height of the upper part of the face $(16.0 \%)$. the largest length of the head. the length of the body of the mandible on the left. and the morphological face length $(12.0 \%) ; 3$ models of crown height $\left(R^{2}=0.507\right.$ $0.632)$. which most often include the outer-eye width $(18.7 \%)$ and the transverse arc and length of the body of the mandible on the left (12.5\%); only 1 model of mesio-

\section{References}

[1] Alekseev, V. P., \& Debets, G. F. (1964). Craniometry: anthropological research methodology. M.: Science.

[2] Almond, J. R., Leroux, B. G., Knight, D. J., \& Ramsay, D. S. (1999). Craniofacial morphology and tooth wear: A longitudinal study of orthodontic patients. Angle orthod., 69(1), 7-13. doi: 10.1043/0003-3219(1999)069<0007:C>2.3.CO;2.

[3] Bedoya, A., Osorio, J. C., \& Tamayo, J. A., (2015). Dental Arch Size. Biting Force. Bizygomatic Width and Face Height in Three Colombian Ethnic Groups. International Journal of Morphology, 33(1), 55-61. http://dx.doi.org/10.4067/ S0717-95022015000100009.

[4] Bland, J. M., \& Altman, D. G. (1986) Statistical methods for assessing agreement between two methods of clinical measurement. Lancet, 1, 307-310. PMID: 2868172.

[5] El-Zanaty, H. M., El-Beialy, A. R., Abou El-Ezz, A. M., Attia, K. H., El-Bialy, A. R., \& Mostafa, Y. A. (2010). Threedimensional dental measurements: an alternative to plaster models. Am. J. Orthod. Dentofacial. Orthop., 137, 259-265. doi: 10.1016/j.ajodo.2008.04.030.

[6] Gayvoronskiy, I. V., Gayvoronskiy, A. I., Gayvoronskaya, M. G., Dubovik, E. I., Kevorkova, S. A., Koltunov, A. V., \& Schanikova, A. S. (2008). Craniometric correlations of the dentoalveolar system. temporomandibular joint and facial skull in an adult. Morphology, 133(2), 29.

[7] Glushak, A. A. (2015). Vestibular-or al size of teeth in boys and girls with orthognathic bite depending on the shape of head and type of face. Reports of Vinnytsia National Medical University, 19(1), 37-43.

[8] Glushak, A. A., Gunas, I. V., Lisnichuk, N. E., \& Samoylenko, A. V. (2015). Vertical dimensions of teeth in adolescents from Podolia with orthognathic bite depending on the shape of head and face type. Problems of Biology and Medicine, 2(83), 28-37.

[9] Lomiashvili, L. M., \& Pogodaev, D. V. (2004). Variability of the forms of molars of the dentoalveolar apparatus of man. Institute of Stomatology, 4, 74-77. distal dimensions $\left(R^{2}=0.509\right)$ and 3 models of crown height $\left(R^{2}=0.564-0.702\right)$ were constructed in men of the Southern region of Ukraine. which most often include the height of the forehead $(17.6 \%)$. the largest girth of the head. the width of the base nose. inter-orbital width and length of the body of the mandible on the right (11.8\%).

The regression models of the linear sizes of molars. constructed by us. depending on the features of cephalometric indices. craniotype and the type of face of men in the Northern and Southern regions of Ukraine. will allow doctors to eliminate relevant medical and diagnostic problems in dentistry and preventive medicine.

\section{Conclusion}

In practically healthy men from the Northern and Southern administrative-territorial regions of Ukraine. based on the specifics of cephalometric indices. craniotype and face type. reliable regression models (with determination coefficient $R^{2}$ greater than 0.5 ) of individual linear computational-tomographic sizes of molars of the upper and lower jaw (out of 40 possible 7 for Northern and 12 for Southern regions of Ukraine) are made.

[10] Lutskaya, I. K. (2003). Aesthetic function of the tooth. Scientific and practical journal. Modern dentistry, 1, 30-37.

[11] Lyakh, Yu. E., Gurjanov, V. G., Homenko, V. N., \& Panchenko, O. A. (2006). Fundamentals of computer biostatistics. Analysis of information in biology. medicine and pharmacy by statistical package MedStat. D.: Papakica E. K. ISBN 966-96255-2-1.

[12] Nada, R. M., Maal, T. J., Breuning, K. H., Berge, S. J., Mostafa, Y. A., KuijpersJagtman, A. M. (2011). Accuracy and reproducibility of voxel based superimposition of cone beam computed tomography models on the anterior cranial base and the zygomatic arches. PloS One 2011; 6:e16520. doi: 10.1371/journal.pone.0016520.

[13] Orlovskiy, V. O., Shinkaruk-Dykovytska, M. M., \& Gunas, I. V. (2018). Modeling using regression analysis of individual linear dimensions of premolars depending on cephalometric indicators of practically healthy men from different regions of Ukraine. Bulletin of scientific research, 1, 90-95. doi: 10.11603/2415-8798.2018.1.8737.

[14] Pachêco-Pereira, C., Canto, G. D. L., Major, P. W., \& FloresMir, C. (2014). Variation of orthodontic treatment decisionmaking based on dental model type: A systematic review. The Angle Orthodontist, 85(3), 501-509. https://doi.org/ 10.2319/051214-343.1.

[15] Piao, Y., Kim, S. J., Yu, H. S., Cha, J. Y., Baik, H. S. (2016). Five-year investigation of a large orthodontic patient population at a dental hospital in South Korea. The Korean Journal of Orthodontics, 46(3), 137-145. doi: 10.4041/ kjod.2016.46.3.137.

[16] Plokhinsky, N. A. (1980). Biometric algorithms. M.: Publishing house MGU.

[17] Proffit, U. R. (translation from English; Ed. L. S. Persina) (2015). Modern orthodontics. M.: Medpress-inform. ISBN: 978-5-00030-236-1.

[18] Sandro, B., \& Razionale, A. V. (2013). Creation of 3D multibody orthodontic models by using independent imaging 
sensors. Sensors, 13(2), 2033-2050. doi: 10.3390/ s130202033.

[19] Shinkaruk-Dikovitska, M. M., \& Orlovskiy, V. O. (2017). Differences linear dimensions small molar teeth and their roots in practically healthy men from Ukraine with different types faces. World of Medicine and Biology, 2(60), 124-126.

[20] Slavicek, G. (2011). Cephalometrie. Berlin : Steinbeis-Ed. ISBN 9783941417724

[21] Slavicek, R. (2006). The Masticatory Organ. Function and Dysfunction. Vienna - Klosterneuburg : Gamma Med.-wiss. ISBN 39501261129783950126112.

[22] Samusev, R. P., Krayushkin, A. I., Dmitrienko, S. V, (Ed. M. R. Sapin) (2002). Basics of clinical morphology of teeth: a tutorial. M.: OOO "Publishing House "ONIX 21 vek": OOO "World and Education". ISBN: 5-329-00426-8.

[23] Trezubov, V. N., Bulycheva, E. A., Chikunov, S. O., Trezubov, V. V., \& Alpatyeva, U. V. (2015). The cephalometric study of the facial skeleton during the preparation to eliminating the occlusal surface deformations of dentition. Institute of Stomatology, 4, 102-104.

[24] Zilberman, O., Huggare, J. A., \& Parikakis, K. A. (2003). Evaluation of the validity of tooth size and arch width measurements using conventional and three-dimensional virtual orthodontic models. Angle Orthod., 73(3), 301-306.

[25] Zubov, A. A. (1968). Odontology. Methodology of anthropological research. M.: Science.

Коцюра 0.0 .

МОДЕЛЮВАННЯ ЗА ДОПОМОГОЮ РЕГРЕСІЙНОГО АНАЛІЗУ ЛІНІЙНИХ РОЗМІРІВ ВЕЛИКИХ КУТНІХ

ЗУБІВ В ЗАЛЕЖНОСТІ ВІД ЦЕФАЛОМЕТРИЧНИХ ПОКАЗНИКІВ ПРАКТИЧНО ЗДОРОВИХ ЧОЛОВІКІВ ПІВНІЧНОГО І ПІВДЕННОГО РЕГІОНІВ УКРАЇНИ

Для здійснення більш точної одонтометрії. враховуючи індивідуальні краніотипологічні особливості пацієнта. потрібно застосовувати математичне моделювання. що дозволить значно підвищити якість лікувально-діагностичного процесу в ортодонтії. Мета дослідження - побудувати та провести аналіз регресійних моделей комп'ютерно-томографічних розмірів великих кутніх зубів в залежності від особливостей цефалометричних показників практично здорових чоловіків Північного $i$ Південного регіонів України. Проведено комп'ютерно-томографічне дослідження великих кутніх зубів із наступними одонтометрією і цефалометрією 32 практично здоровим чоловікам Північного регіону України - мешканці з Житомирської. Київської. Чернігівської та Сумської областей та 33 чоловікам Південного регіону України - мешканці з Одеської. Миколаївської. Херсонської. Запорізької областей та АР Крим. Побудову регресійних моделей індивідуальних лінійних розмірів великих кутніх зубів залежно від цефалометричних показників. проводили за допомогою ліцензійного статистичного програмного пакета "Statistica 6.1". В результаті проведених досліджень нами побудовані достовірні моделі лінійних комп'ютерно-томографічних розмірів великих кутніх зубів верхньої і нижньої щелеп у практично здорових чоловіків Північного [3 моделі мезіо-дистальних розмірів $\left(R^{2}=0,576-0,685\right)$ до яких найчастіше входять довжина тіла нижньої щелепи справа (16,7\%). найменша ширина голови. глибина носа та краніотип (по 11,1\%); 2 моделі присінково-язикових розмірів $\left(R^{2}=0,657\right.$ i 0,767) до яких найчастіше входять поперечна дуга та найменша ширина голови (по 15,4\%); 2 моделі висоти коронок $\left(R^{2}=\right.$ 0,519 і 0,557)]. а також Південного [4 моделі мезіо-дистальних розмірів $\left(R^{2}=0,508-0,798\right)$ до яких найчастіше входять найбільша довжина голови. середня ширина обличчя. висота верхньої частини обличчя. фізіологічна довжина обличчя. ширина нижньої щелепи. глибина носа та зовнішньоочна ширина (по 8, 3\%); 6 моделей присінково-язикових розмірів $\left(R^{2}=0,504-\right.$ $0,756)$ до яких найчастіше входять зовнішньоочна ширина (13,2\%). фізіологічна довжина обличчя. міжочноямкова ширина та ширина ротової щілини (по 10,5\%). найбільша ширина голови. довжина та висота носа (по 7,9\%). поперечна дуга. висота верхньої частини обличчя та відстань між назіон та міжрізцевою точкою (по 5,3\%); 2 моделі висоти коронок $\left(R^{2}=0,527\right.$ i 0,748) до яких найчастіше входять міжочноямкова ширина та ширина ротової щілини (по 14,3\%)] регіонів України. Таким чином у практично здорових чоловіків із Північного і Південного адміністративно-територіальних регіонів України на основі особливостей цефалометричних показників. краніотипу та типу обличчя розроблені достовірні регресійні моделі (з коефіцієнтом детермінації $R^{2}$ більшим ніж 0,5) індивідуальних лінійних комп'ютерно-томографічних розмірів великих кутніх зубів верхньої $і$ нижньої щелеп (із 40 можливих 7 для Північного і 12 для Південного регіонів України).

Ключові слова: регресійні моделі, великі кутні зуби, лінійні розміри, комп'ютерна томографія, цефалометрія, практично здорові чоловіки, Північний і Південний регіони України.

\section{Коцюра O.A. \\ МОДЕЛИРОВАНИЕ С ПОМОЩЬЮ РЕГРЕССИОННОГО АНАЛИЗА ЛИНЕЙНЫХ РАЗМЕРОВ БОЛЬШИХ КОРЕННЫХ ЗУБОВ В ЗАВИСИМОСТИ ОТ ЦЕФАЛОМЕТРИЧЕСКИХ ПОКАЗАТЕЛЕЙ ПРАКТИЧЕСКИ ЗДОРОВЫХ МУЖЧИН СЕВЕРНОГО И ЮЖНОГО РЕГИОНОВ УКРАИНЫ}

Для осуществления более точной одонтометрии, учитывающей индивидуальные краниотипологические особенности пациента, необходимо использовать математическое моделирование, что позволит значительно повысить качество лечебно-диагностического процесса в ортодонтии, Цель исследования - построить и провести анализ регрессионных моделей компьютерно-томографических размеров больших коренных зубов в зависимости от особенностей цефалометрических показателей практически здоровых мужчин Северного и Южного регионов Украины, Проведено компьютерно-томографическое исследование больших коренных зубов со следующими одонтометрией и цефалометрией 32 практически здоровым мужчинам Северного региона Украины - жители из Житомирской, Киевской, Черниговской и Сумской областей и 33 мужчинам Южного региона Украины - жители из Одесской, Николаевской, Херсонской, Запорожской областей и АР Крым, Построение регрессионных моделей индивидуальных линейных размеров крупных коренных зубов в зависимости от цефалометрических показателей, проводили с помощью лицензионного статистического программного пакета "Statistica 6,1", В результате проведенных исследований нами построены достоверные модели линейных компьютерно-томографических размеров больших коренных зубов верхней и нижней челюсти у практически здоровых мужчин Северного [3 модели мезио-дистальных размеров $\left(R^{2}=0,576-0,685\right)$ к которым чаще всего входят длина тела нижней челюсти справа (16,7\%), наименьшая ширина головы, глубина носа и краниотип (по 11,1\%); 2 модели преддверно- 
языковых размеров ( $R 2=0,657$ и 0,767) к которым чаще всего входят поперечная дуга и наименьшая ширина головы (по 15,4\%); 2 модели высоты коронок $\left(R^{2}=0,519\right.$ и 0,557)], а также Южного [4 модели мезио-дистальных размеров $\left(R^{2}=0,508\right.$ $0,798)$ к которым чаще всего входят наибольшая длина головы, средняя ширина лица, высота верхней части лица, физиологическая длина лица, ширина нижней челюсти, глубина носа и внешнеглазная ширина (по 8,3\%); 6 моделей преддверно-языковых размеров $\left(R^{2}=0,504-0,756\right)$ к которым чаще всего входят внешнеглазная ширина (13,2\%), физиологическая длина лица, между глазничная ширина и ширина ротовой щели (по 10,5\%), наибольшая ширина головы, длина и высота носа (по 7,9\%), поперечная дуга, высота верхней части лица и расстояние между назион и между резцовой точкой (по 5,3\%); 2 модели высоты коронок $\left(R^{2}=0,527\right.$ и 0,748) к которым чаще всего входят между глазничная ширина и ширина ротовой щели (по 14,3\%)] регионов Украины, Таким образом у практически здоровых мужчин с Северного и Южного административно-территориальных регионов Украины на основе особенностей цефалометрических показателей, краниотипа и типа лица разработаны достоверные регрессионные модели (с коэффициентом детерминации $R^{2}$ большим 0,5) индивидуальных линейных компьютерно-томографических размеров больших коренных зубов верхней и нижней челюстей (с 40 возможных 7 для Северного и 12 для Южного регионов Украины),

Ключевые слова: регрессионные модели, большие коренные зубы, линейные размеры, компьютерная томография, цефалометрия, практически здоровые мужчины, Северный и Южный регионы Украины. 